CLINICAL STUDY

\title{
The IGF system after insertion of a transjugular intrahepatic porto-systemic shunt in patients with liver cirrhosis
}

\author{
Peter Holland-Fischer ${ }^{1}$, Hendrik Vilstrup ${ }^{1}$, Jan Frystyk ${ }^{2}$, Dennis Tønner Nielsen ${ }^{3}$, Allan Flyvbjerg ${ }^{2}$ \\ and Henning Grønbæk ${ }^{1}$ \\ ${ }^{1}$ Department of Medicine V (Hepatology and Gastroenterology), ${ }^{2}$ Medical Department M (Diabetes and Endocrinology) and the Medical Research \\ Laboratories, Clinical Institute and ${ }^{3}$ Department of Radiology R, Aarhus University Hospital, Noerrebrogade 44, 8000 Aarhus C, Denmark
}

(Correspondence should be addressed to P Holland-Fischer; Email: phf@svf.au.dk)

\begin{abstract}
Objective: Insertion of a transjugular intrahepatic porto-systemic shunt (TIPS) into patients with liver cirrhosis usually induces a gain in body cell mass. Changes in the IGF system in favor of anabolism may be involved. We, therefore measured blood concentrations of the components of the IGF system in cirrhosis patients before and after elective TIPS.

Design and methods: The study comprised 17 patients and 11 healthy controls. Patients were examined before and 1, 4, 12, and 52 weeks after TIPS. Biochemical analyses of the IGF system were compared with changes in body composition (bioimpedance analysis), glucose and insulin, and metabolic liver function (galactose elimination capacity).

Results: After TIPS, body cell mass rose by $3.2 \mathrm{~kg}$ (95\% confidence interval (CI): 1.0-5.5) at 52 weeks, in correlation with baseline liver function $\left(r^{2}=0.22 ; P=0.03\right)$. Peripheral blood concentrations of total IGF1 and 2, bioactive IGF1, and the IGF-binding proteins (IGFBP-1, -2, and -3) remained unchanged throughout the study period. There was no change in fasting glucose, whereas fasting insulin rose by $40 \%$ (CI: $11-77 \%$ ) and glucagon by $58 \%$ (CI: $11-132 \%$ ) from baseline to 52 weeks after TIPS. Conclusion: Our data confirm that TIPS was associated with an increase in body cell mass in patients with liver cirrhosis, but without any change in the circulating IGF system. Thus, the results do not support the notion that effects on the circulating IGF system are involved in the anabolic effects of TIPS insertion.
\end{abstract}

European Journal of Endocrinology $160957-963$

\section{Introduction}

Patients with liver cirrhosis often suffer from severe hepatic malnutrition with loss of body tissue that is difficult to treat and carries a sinister prognosis in terms of increased morbidity and mortality (1-3).

Since the introduction of transjugular intrahepatic porto-systemic shunt (TIPS) as a clinical procedure to reduce portal hypertension, it was observed that the procedure is frequently associated with marked nutritional improvement and gain in body cell mass $(4,5)$. The underlying mechanism is unknown, but it is important to identify in order to improve the pathophysiological understanding of the metabolic consequences of portal hypertension and because it may imply pharmacological treatment possibilities of malnutrition also in patients who are unable to receive a TIPS.

Patients with cirrhosis and portal hypertension are known to have significant changes in their insulin-like growth factor (IGF) system and its interaction with insulin that may play a role for their loss of body mass (6-9). Therefore, it is an obvious possibility that TIPS changes the prevailing IGF system and insulin levels in a way that contributes towards improved nutrition (10-12). Still, the effects of TIPS on the IGF system have not been systematically described.

The IGF system comprises the peptides IGF1 and 2 in free and bound forms and their IGF-binding proteins (IGFBP-1 to -6). The small free-peptide fractions exert most of the growth-regulating effects, but also the IGFBPs are active, and regulation of them influences the IGF bioactivity. The peptide-free fractions and insulin interact in anabolism via an insulin effect on IGFBP-1 and -2 (13-15). The liver plays a central regulatory role for the system as a whole, both by synthesizing several of the components of the system, and by modifying portal-derived substances, including insulin (16-18).

Our a priori expectation was that insertion of TIPS in patients with cirrhosis would induce significant changes in the deranged IGF system, which are compatible with anabolism.

The primary purpose of our work, therefore, was to map the components of the circulating IGF system in cirrhosis patients before and after TIPS. The secondary purpose was to relate these findings to changes in body composition and liver function. 


\section{Methods}

\section{Subjects and ethics}

Twenty-six patients with liver cirrhosis set to undergo an elective TIPS procedure were consecutively enrolled. Three never completed the baseline examination due to variceal bleeding demanding intensive care and immediate TIPS insertion. Out of the remaining 23 (15 males and eight females) patients, one underwent orthotopic liver transplantation, two died during followup, and three refused to participate in follow-up. Thus, 17 patients completed the study (Fig. 1). The diagnosis of cirrhosis was established by a combination of biochemical, clinical, and ultrasonographic findings and confirmed by liver biopsy in eight cases. The etiologies were alcohol intake $(n=13)$, autoimmune hepatitis $(n=2)$, primary sclerosing cholangitis $(n=1)$, or unknown $(n=1)$. Abstinence from alcohol was a goal during the study, and to our knowledge all save one adhered to that policy.

As controls, we studied 11 normal healthy volunteers recruited among hospital staff and matched for body mass index (BMI), sex, and age. All gave written informed consent to their participation in accordance with the Helsinki Declaration. The study was approved by the Research Ethics Committee of Aarhus.

\section{Experimental design}

The patients were studied within 2 weeks before TIPS insertion. Post-TIPS examinations were carried out 1,4 , 12 , and 52 weeks after the procedure. All subjects were examined after an overnight fast. Seven patients with moderate or tense ascites underwent paracentesis prior to the pre-TIPS examination.

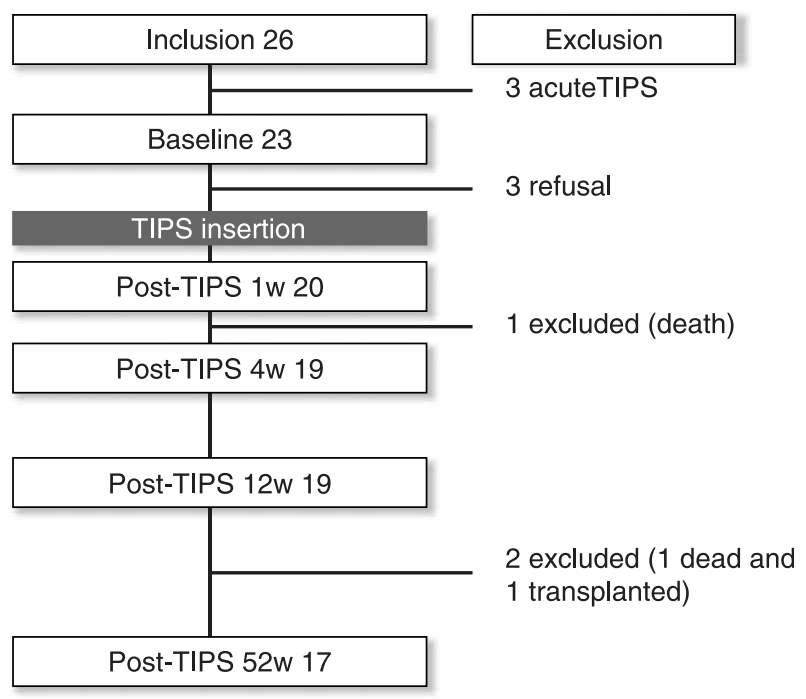

Figure 1 Flow chart. Number in boxes refers to number of patients. Grey horizontal bar indicates TIPS insertion and black horizontal line indicates exclusion of participants as indicated.

\section{Nutritional therapy and assessment of energy intake}

All patients received standard nutritional education and therapy according to European Society for Clinical Nutrition and Metabolism guidelines during TIPS evaluation and follow-up (19). The therapy was handled by a clinical dietician. Energy and protein intake were assessed by systematic dietary recall and food diary during hospital admission. All TIPS patients, except two, underwent a baseline assessment, and a random sample of eight patients was comprehensively assessed 12-26 weeks after TIPS insertion. Energy expenditure was calculated using Harris and Benedict's equation with the use of total body weight, in those with ascites after paracentesis (20).

\section{TIPS procedure}

Indications for TIPS insertion were refractory ascites (10 patients), secondary prevention of variceal rebleeding (five patients), or a combination (two patients). None had active variceal bleeding at the time for TIPS insertion. The TIPS was inserted using covered stents according to the method described by Rössle et al. (21). After insertion, clinical and ultrasonographic shunt controls were performed after $24 \mathrm{~h}, 4$ weeks, and then every 12 weeks for the first year. There was no procedure-related complication. The porto-systemic pressure gradient was lowered from a median of 16 (range 10-29) to 6 (range 2-10) mmHg. Three patients needed stent revision during follow-up. Transient hepatic encephalopathy was observed in three patients and reverted on diet and laxatives without the need for shunt reduction.

\section{Biochemical analyses}

Blood samples were placed on ice, centrifuged at $5^{\circ} \mathrm{C}$, separated, and stored at $-80{ }^{\circ} \mathrm{C}$ until analysis. Plasma glucose concentrations were determined after sampling (Beckman Instruments, Palo Alto, CA, USA). Serum insulin concentrations were measured by a two-site immunospecific insulin ELISA (22). Plasma glucagon concentrations were determined by RIA, as described by Orskov et al. (23). GH was measured using a commercial immunofluorometric assay (24). Serum total IGF1 and 2 were determined following acid ethanol extraction by in-house monoclonal time-resolved immunofluorometric assays (25). IGF1 bioactivity was determined by an in-house kinase receptor activation assay based on transfected cells (26). IGFBP-1 and -2 were determined by in-house immunoassays as previously described (27). IGFBP-3 was measured using a commercial IRMA (BioSource, Nivelles, Belgien). All measurements were performed in duplicates. 


\section{Liver function}

Clinical status was assessed according to the model for end-stage liver disease score (MELD). The galactose elimination capacity (GEC) was used to quantitatively measure metabolic liver function. The GEC was determined from blood concentration decay curves corrected for urinary excretion, as described by Tygstrup (28).

\section{Insulin resistance}

Homeostasis model assessment (HOMA) insulin resistance (IR) index was calculated using simultaneous fasting insulin and glucose levels (29).

\section{Body composition}

Bioimpedance analysis (Quadscan 4000, Bodystat Ltd, Isle of Man, UK) was used to estimate body composition, in patients with ascites after paracentesis. The predictive equations are taken from Kushner et al. and Lautz et al. $(30,31)$. We focused on body cell mass, because this estimate constitutes metabolically active cells and is relatively independent on the degree of ascites during serial measurements (32).

\section{Statistics analysis}

Data analysis was performed using STATA 10 statistical software (StataCorp LP, College Station, TX, USA). Results are given as mean \pm s.D. except for the IGF system in which results are presented as median (lower quartile-upper quartile). Changes from baseline were explored by ANOVA for repeated measurements. Due to non-systematic factors, blood samples were missing from eight examinations in six patients. For the statistical analyses, these missing values were replaced by the mean of adjacent values or, in case of missing 52 weeks values, the last observation was carried forward. Controls and the baseline groups were compared by unpaired Students $t$-test. The variables regarding the growth factor system, glucagon, and insulin depended on logarithmic transformation before parametric methods could be applied. Correlation between variables was examined by linear regression at baseline and 52 weeks time points. A $P$ value $<0.05$ was considered significant in a two-tailed test.

\section{Results}

\section{Patient characteristics}

Patients had a mean age of 56 (25-78) years and a BMI of $25(17-37) \mathrm{kg} / \mathrm{m}^{2}$, similar to controls with age 57 (35-64) years and BMI 24 (19-28) $\mathrm{kg} / \mathrm{m}^{2}$. After TIPS, one patient died because of alcohol abuse, one died, and one underwent liver transplantation due to liver failure.

At 52 weeks after TIPS, GEC had fallen from 59 to $52 \%$ of expected value (difference $-7 \%$, CI: -15 to -1$)$. Mean MELD score was 8 (1-21) before TIPS and did not change (Table 1 ).

\section{Body composition}

At baseline, body cell mass was $6.7 \mathrm{~kg}$ (CI: 0.5-12.9) lower than controls. After TIPS, body cell mass rose on average by $2.6 \mathrm{~kg}$ (CI: $0.2-4.9$ ) at 12 weeks and by $3.2 \mathrm{~kg}$ (CI: 1.0-5.5) at 52 weeks (Table 1). Thirteen patients increased their cell mass. The maximum change in body cell mass (BCM) correlated moderately with the baseline GEC $\left(r^{2}=0.25, P=0.03\right)$.

\section{IGFs and IGFBPs}

Before TIPS insertion, the patients had reduced blood concentrations of total IGF1, bioactive IGF1, and IGFBP-3 compared with controls, whereas GH, IGFBP-1 and -2 were increased (Fig. 2). After TIPS, the concentrations remained unchanged during the 52-week study period. GEC correlated with bioactive IGF1 before $\left(r^{2}=0.30, P=0.02\right)$ and 52 weeks after TIPS $\left(r^{2}=0.41, P=0.003\right)$ and also with IGFBP-3 at both examinations (baseline: $r^{2}=0.20, P=0.04 ; 52$ weeks: $\left.r^{2}=0.25, P=0.03\right)$. Patients had reduced total IGF2 levels compared with controls (339 (298-592) vs

Table 1 Body composition and liver function.

\begin{tabular}{|c|c|c|c|c|c|c|c|c|}
\hline & $\begin{array}{c}\text { Controls } \\
n=11\end{array}$ & $\begin{array}{c}\text { TIPS } \\
\text { baseline } \\
n=17\end{array}$ & $\begin{array}{c}\text { TIPS } \\
1 \text { week } \\
n=17\end{array}$ & $\begin{array}{c}\text { TIPS } \\
4 \text { weeks } \\
n=17\end{array}$ & $\begin{array}{c}\text { TIPS } \\
12 \text { weeks } \\
n=17\end{array}$ & $\begin{array}{c}\text { TIPS } \\
52 \text { weeks } \\
n=17\end{array}$ & $\begin{array}{l}\text { Equality } \\
\text { of TIPS } \\
\text { groups }\end{array}$ & $\begin{array}{c}\text { Controls } \\
\text { versus TIPS } \\
\text { baseline }\end{array}$ \\
\hline Weight (kg) & $74.1 \pm 14.6$ & $76.6 \pm 19.5$ & $75.7 \pm 16.7$ & $79.1 \pm 18.1$ & $79.7 \pm 18.1$ & $80.9 \pm 19.6$ & $P=0.18$ & $P=0.62$ \\
\hline Body cell mass $(\mathrm{kg})$ & $31.9 \pm 8.1^{\mathrm{a}}$ & $25.2 \pm 8.4$ & $26.5 \pm 8.4$ & $26.8 \pm 8.4$ & $27.8 \pm 9.1^{\mathrm{a}}$ & $28.5 \pm 9.6^{\mathrm{a}}$ & $P=0.03$ & $P=0.034$ \\
\hline $\begin{array}{l}\text { GEC percentage of } \\
\text { expected value }\end{array}$ & NID & $59 \pm 13$ & $57 \pm 10$ & $55 \pm 11$ & $54 \pm 10$ & $52 \pm 9^{\mathrm{a}}$ & $P=0.04$ & ND \\
\hline MELD score & $1 \pm 0.2^{\mathrm{a}}$ & $8.3 \pm 5.3$ & $9.8 \pm 4.5$ & $9.9 \pm 3.6$ & $9.9 \pm 4.3$ & $10.3 \pm 4.8$ & $P=0.40$ & $P<0.001$ \\
\hline
\end{tabular}

Data on body composition are determined by bioimpedance analysis. For each continuous variable, results are shown as mean \pm s.D. GEC, galactose elimination capacity; $n$, number of non-missing values; ND, not done.

${ }^{a}$ Denotes significant change from baseline. 

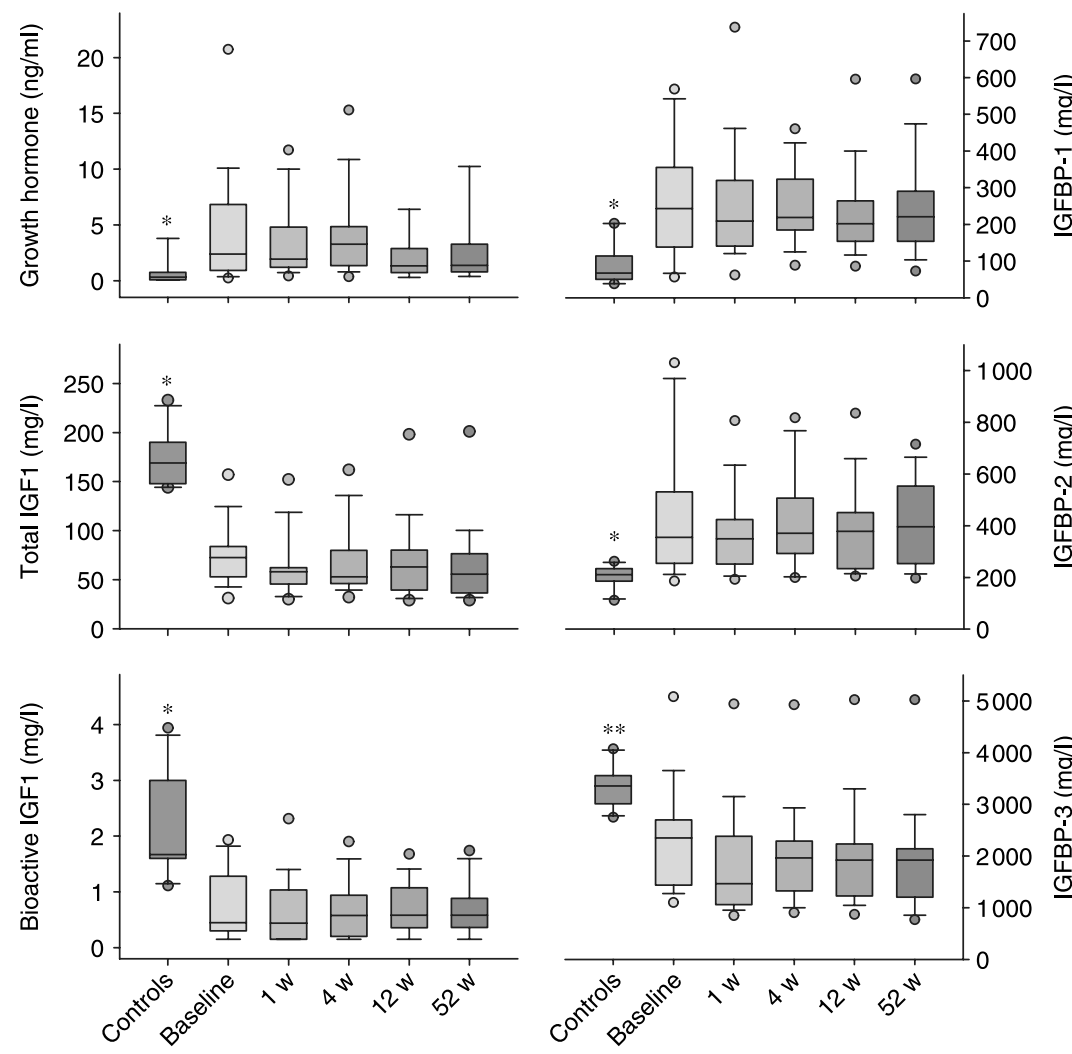

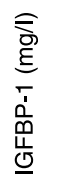

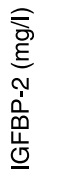

Figure 2 Components of the growth factor system in controls and before (baseline) and after TIPS insertion $(1,4,12$, and 52 weeks respectively). Boxes display median with lower and upper quartile, whiskers indicates the $95 \%$ interval and circles represents outliers. The symbol * denotes $P<0.001$ and ${ }^{* \star} P<0.01$ compared with baseline (ANOVA).
1076 (1001-1164) mg/l; $P<0.001$ ), which did not change during follow-up.

Bioactive IGF1 correlated negatively with IGFBP-1 before TIPS $\left(r^{2}=0.33 ; P=0.003\right)$ and after 52 weeks $\left(r^{2}=0.25, P=0.02\right)$. There was a positive correlation with total IGF1 before TIPS $\left(r^{2}=0.25, P=0.02\right)$ and after 52 weeks $\left(r^{2}=0.24, P=0.03\right)$, as well as with IGFBP-3 before TIPS $\left(r^{2}=0.41 ; P=0.001\right)$ and after 52 weeks $\left(r^{2}=0.23, P=0.03\right)$. Bioactive IGF1 did not correlate with GH, IGFBP-2, or insulin levels.

IGFBP-1 and -2 showed a moderate negative correlation with insulin before TIPS (IGFBP-1: $r^{2}=0.33, P=0.003 ;$ IGFBP-2: $\left.r^{2}=0.23, P=0.04\right)$ and also after 52 weeks (IGFBP-1: $r^{2}=0.33$, $P=0.003$; IGFBP-2: $\left.r^{2}=0.25, P=0.02\right)$.

\section{Glucose, insulin, glucagon, and HOMA index}

There was no difference in fasting glucose between the cirrhosis group before TIPS and controls, or in the cirrhosis group after TIPS. Fasting insulin was higher in the cirrhosis group before TIPS than in controls, and rose further by $40 \%(11-77 \%) 52$ weeks after TIPS (Table 2). Correspondingly, the HOMA index of IR increased by $46 \%(11-93 \%)$ at 52 weeks. GH correlated negatively with insulin $\left(r^{2}=0.11 ; P=0.015\right)$, but no linear relationship was found with HOMA index of IR. The increase in insulin was paralleled by glucagon with levels being doubled at 52 weeks, and the two variables were positively associated both before and after TIPS insertion $\left(r^{2}=0.29, P<0.001\right)$.

Table 2 Glucose, insulin, glucagon, and homeostasis model assessment-insulin resistance (HOMA-IR).

\begin{tabular}{|c|c|c|c|c|c|c|c|c|}
\hline & $\begin{array}{c}\text { Controls } \\
n=11\end{array}$ & $\begin{array}{c}\text { TIPS } \\
\text { baseline } \\
n=17\end{array}$ & $\begin{array}{c}\text { TIPS } \\
1 \text { week } \\
n=16\end{array}$ & $\begin{array}{c}\text { TIPS } \\
4 \text { weeks } \\
n=14\end{array}$ & $\begin{array}{c}\text { TIPS } \\
12 \text { weeks } \\
n=17\end{array}$ & $\begin{array}{c}\text { TIPS } \\
52 \text { weeks } \\
n=15\end{array}$ & $\begin{array}{l}\text { Equality } \\
\text { of TIPS } \\
\text { groups }\end{array}$ & $\begin{array}{c}\text { Controls } \\
\text { versus } \\
\text { TIPS } \\
\text { baseline }\end{array}$ \\
\hline Gluc & 5. & 5. & 5 & 6.0 & 5.9 & 6.0 & $P$ & 2 \\
\hline Insulin (p & $7^{a}$ & $125 \pm$ & $151=$ & $183 \pm$ & $184 \pm$ & $172 \pm$ & $P=0.025$ & $P=0.002$ \\
\hline $\begin{array}{l}\text { Insulin resistance } \\
\text { HOMA index }\end{array}$ & $1.2 \pm 0.7^{\mathrm{a}}$ & $4.7 \pm 3.7$ & $5.2 \pm 3.6$ & $7.3 \pm 6.0$ & $7.3 \pm 5.8$ & $7.7 \pm 5.7^{\mathrm{a}}$ & $P=0.048$ & $P=0.005$ \\
\hline Glucagon (pmol/l) & $39(30-75)$ & $168(89-375)$ & $172(125-332)$ & $252(112-441)$ & $298(145-354)$ & $298(108-659)^{\mathrm{a}}$ & $P<0.001$ & $P<0.001$ \\
\hline
\end{tabular}

Results are given as mean \pm s.D. or median (lower quartile-upper quartile). Insulin resistance is calculated by the HOMA nomogram method where the value 1 represents the average healthy 35 -year-old male. $n$, number of non-missing values.

aDenotes significant change from baseline. 


\section{Energy and protein intake}

Energy intake before TIPS was $7385 \pm 1068 \mathrm{~kJ} /$ day equal to $80 \%$ of the predicted energy requirement of $9185 \pm 1070 \mathrm{~kJ} /$ day $(P<0.001)$. Protein intake was $65 \pm 12 \mathrm{~g}$ protein per day corresponding to $74 \%$ of predicted requirement. Eight patients with complete dietary record had an energy intake of $7215 \pm 340 \mathrm{~kJ} /$ day before and $7630 \pm 620 \mathrm{~kJ} /$ day after TIPS $(P=0.56)$ equal to $76 \%$ of predicted requirement.

\section{High gainers versus low gainers}

As an exploratory post hoc analysis, patients were divided into a body cell mass high-gain group $(n=10)$ and a low gain $(n=7)$ with an arbitrary discrimination value of $2.0 \mathrm{~kg}$ gain in BCM. There was no difference in either GEC, MELD score, or in bioactive IGF1 before TIPS between these groups, whereas HOMA calculated IR before TIPS tended to be higher among the low gainers (6.7 vs $2.8, P=0.06)$.

\section{Discussion}

Our main finding was that TIPS neither acutely nor during follow-up changed the blood concentration of any component of the IGF system of the cirrhosis patients, even though their body cell mass rose. This finding is in contrast to our a priori expectation. The improvement in nutrition correlated positively with baseline liver function and marginally negatively with baseline IR.

Only total IGF1 has been studied previously in relationship to TIPS insertion, and as in our study its concentration did not change 1 month after the procedure (33). Both the malnutrition with low BCM in patients compared with controls and the observed increase after TIPS is in agreement with previous studies $(4,5,34)$. Body weight only tended to increase which is explained by the resolution of ascites masking the non-water weight gain.

We expected that TIPS insertion with shunting of insulin-rich portal blood to the systemic circulation would increase the circulating blood concentration of bioactive IGF1 by decreasing levels of the inhibitory IGFBP-1 and -2 (13-15). Peripheral insulin levels did indeed increase markedly, implying that our data are not compatible with this mechanism. Also, there was no change in any other component of the IGF system, and there was no relationship between changes in body composition and the IGF system.

There may be several explanations for the lack of increase in activity of the IGF system after TIPS. The most likely one is related to the central function of the liver in both producing the key components of the system and being the main site for the interaction between them and insulin. Animal experiments show that the majority of the circulating IGF1 pool and IGFBPs originates from the liver $(35,36)$. The reduction in metabolic liver function after TIPS, as measured by the decrease in GEC, may explain the lack of change in circulating IGF1 after TIPS (37). Another possible explanation is related to the fact that the production of key components of the growth factor system is also nutritionally regulated (38). We did not identify a consistent increase in energy intake after TIPS, and this might limit an increase in IGF1. Insulin is an important regulator of IGF1 by controlling the hepatic GH receptor expression and hence $\mathrm{GH}$ sensitivity. Furthermore, insulin inhibits the hepatic synthesis of IGFBP-1 and -2, thereby increasing IGF1 bioactivity (14). We found no increase in IGF1 bioactivity or any reductions in the two insulin-sensitive IGFBPs. This may reflect that the sinusoidal hepatocyte exposure to insulin remained unchanged or even reduced, despite the elevated peripheral blood insulin concentration. This could be due to insulin-rich portal bypassing the sinusoids via the TIPS, so that sinusoidal perfusion in that situation was mostly dependent on arterial and relatively insulindepleted blood supply (39-41). Studies in dogs with shifting of insulin release from the portal to a peripheral vein immediately doubles peripheral blood insulin concentration, halves the sinusoidal concentration (42), and doubles the hepatic glucose output. This mechanism would partly explain the observed euglycemia despite the marked peripheral hyperinsulinemia.

Still, since many components of the IGF system are synthesized in non-hepatic tissues, we cannot exclude that some of the effects of TIPS on body composition are related to local (i.e. paracrine and/or autocrine) effects of the IGF system, not reflected by changes in the circulation.

The fasting euglycemia, the hyperinsulinemia, and the increased HOMA-calculated IR are in accordance with previous studies $(33,43)$. Others report no change in peripheral IR using the hyperinsulinemic clamp technique (43). It should be noted that GH, which is elevated in cirrhosis and associated with IR (44), did not change after TIPS. Baseline hyperglucagonemia aggravated after TIPS insertion. This observation has been made by others, and is often interpreted as a counterregulatory response to hyperinsulinemia. This would be in agreement with our finding of a positive association between insulin and glucagon (45). It may, however, as well be a direct consequence of the porto-systemic shunting and reduced hepatic degradation. We found that the increase in insulin was not associated with the gain in body cell mass. The trend towards lower baseline HOMA-calculated IR among high gainers is likely to be interrelated with the better metabolic liver function. In any case, our findings of the possible importance of baseline metabolic state for the body cell mass gain after TIPS may have the implication that a relatively good clinical condition of the patient is important to obtain the favorable nutritional effect of TIPS - and more so than TIPS-related effects on the IGF system.

Insertion of a TIPS and the alleviation of portal hypertension have several effects that are likely to shift 
the metabolic homeostasis from catabolic to anabolic. The frequency of stressful and catabolic events like esophageal bleeding, ascites, and bacterial peritonitis is effectively reduced.

Portal hypertension with ascites reduces dietary intake, by decreasing inducing nausea and promoting postprandial fullness (46). The impact of TIPS on energy intake has been addressed by Plauth et al. who found that protein and energy intakes were higher after TIPS, whereas Allard et al. like us, did not detect any consistent change $(4,5)$. However, precise determination of energy intake is difficult and uncertain and even small changes in daily energy intake result in large variation in body weight over time. Overall, we found an increase in energy intake by $415 \mathrm{~kJ} /$ day, which is in itself statistically non-significant, but nonetheless has the potential to induce a $3-4 \mathrm{~kg}$ weight gain if maintained stable during the first year.

Portal hypertension is also associated with intestinal malabsorption and the presence of bacterial products in the abdominal lymph nodes (47-49). Hence, TIPS probably leads to improved nutrient absorption and utilization and reduces the energy consuming lowgrade inflammation (50).

One main limitation of this study is the low number of subjects; implying a risk of a type 2 error and preventing us from identifying baseline predictors for weight gain. As for the measurements of bioactive IGF, however, the variation of these analyses was so low (coefficient of variation $<7 \%$ ) (26) that our results safely preclude major or functionally important effects of TIPS. It was also not possible to include a comparable non-TIPS cirrhosis control group. Accumulation of fluids in patients with liver cirrhosis may produce inaccurate results when bioimpedance measurements are used to determine body cell mass. We used bioimpedance after reducing ascitic patients' body water component. Furthermore, when used during serial measurements on the same patient, the method is remarkably robust and produces stable results largely regardless of the degree of ascites (32). In the same way, the patients' fluid accumulation may also have interfered with our use of BMI to match patients and controls. This, however, would not be important since we used the controls mostly as a reference group for the hormone analyses, the temporal changes after TIPS being our primary goal.

In conclusion, the circulating IGF system did not change after TIPS even though body cell mass increased. Other mechanisms must be involved in the anabolic effect of TIPS, probably involving pre-TIPS metabolic status, portal pressure-related events, or unidentified nutritional effects.

\section{Declaration of interest}

The authors declare that there is no conflict of interest that could be perceived as prejudicing the impartiality of the research reported.

\section{Funding}

This study was supported by grants from Aarhus University Research Fund, Danish Research Council for Health and Disease, and Clinical Institute, Aarhus University Hospital.

\section{Acknowledgements}

The authors wish to thank clinical dietician Mette Borre for expert nutritional assessment and bioanalysts Joan Hansen, Karen Mathiassen, and Kirsten Nyborg for their excellent technical assistance in the measurement of the IGF system.

\section{References}

1 Andersen H, Borre M, Jakobsen J, Andersen PH \& Vilstrup H. Decreased muscle strength in patients with alcoholic liver cirrhosis in relation to nutritional status, alcohol abstinence, liver function, and neuropathy. Hepatology 199827 1200-1206.

2 Merli M, Riggio O \& Dally L. Does malnutrition affect survival in cirrhosis? PINC (Policentrica Italiana Nutrizione Cirrosi) Hepatology 199623 1041-1046.

3 Selberg O, Bottcher J, Tusch G, Pichlmayr R, Henkel E \& Muller MJ. Identification of high- and low-risk patients before liver transplantation: a prospective cohort study of nutritional and metabolic parameters in 150 patients. Hepatology 199725 652-657.

4 Allard JP, Chau J, Sandokji K, Blendis LM \& Wong F. Effects of ascites resolution after successful TIPS on nutrition in cirrhotic patients with refractory ascites. American Journal of Gastroenterology $2001962442-2447$.

5 Plauth M, Schutz T, Buckendahl DP, Kreymann G, Pirlich M, Grungreiff S, Romaniuk P, Ertl S, Weiss ML \& Lochs H. Weight gain after transjugular intrahepatic portosystemic shunt is associated with improvement in body composition in malnourished patients with cirrhosis and hypermetabolism. Journal of Hepatology 2004 40 228-233.

6 Chen JW, Nielsen MF, Caumo A, Vilstrup H, Christiansen JS \& Frystyk J. Changes in bioactive IGF1 and IGF-binding protein-1 during an oral glucose tolerance test in patients with liver cirrhosis. European Journal of Endocrinology 2006155 285-292.

7 Hernandez A, Zorrilla E \& Gershberg H. Decreased insulin production, elevated growth hormone levels, and glucose intolerance in liver disease. Journal of Laboratory and Clinical Medicine 196973 25-33.

8 Samaan NA, Stone DB \& Eckhardt RD. Serum glucose, insulin, and growth hormone in chronic hepatic cirrhosis. Archives of Internal Medicine 1969124 149-152.

9 Wu YL, Ye J, Zhang S, Zhong J \& Xi RP. Clinical significance of serum IGF1, IGF2 and IGFBP-3 in liver cirrhosis. World Journal of Gastroenterology 200410 2740-2743.

10 Fryburg DA, Jahn LA, Hill SA, Oliveras DM \& Barrett EJ. Insulin and insulin-like growth factor-I enhance human skeletal muscle protein anabolism during hyperaminoacidemia by different mechanisms. Journal of Clinical Investigation 199596 1722-1729.

11 Guler HP, Zapf J \& Froesch ER. Short-term metabolic effects of recombinant human insulin-like growth factor I in healthy adults. New England Journal of Medicine 1987317 137-140.

12 Russell-Jones DL, Umpleby AM, Hennessy TR, Bowes SB, ShojaeeMoradie F, Hopkins KD, Jackson NC, Kelly JM, Jones RH \& Sonksen PH. Use of a leucine clamp to demonstrate that IGF1 actively stimulates protein synthesis in normal humans. American Journal of Physiology 1994267 E591-E598.

13 Conover CA, Lee PD, Kanaley JA, Clarkson JT \& Jensen MD. Insulin regulation of insulin-like growth factor binding protein-1 in obese and nonobese humans. Journal of Clinical Endocrinology and Metabolism $1992 \mathbf{7 4} 1355-1360$.

14 Frystyk J. Free insulin-like growth factors - measurements and relationships to growth hormone secretion and glucose homeostasis. Growth Hormone and IGF Research 200414 337-375. 
15 Ooi GT, Tseng LY \& Rechler MM. Post-transcriptional regulation of insulin-like growth factor binding protein-2 mRNA in diabetic rat liver. Biochemical and Biophysical Research Communications 1992 189 1031-1037.

16 Paolisso G, Tagliamonte MR, Rizzo MR, Carella C, Gambardella A. Barbieri M \& Varricchio M. Low plasma insulin-like growth factor-1 concentrations predict worsening of insulin-mediated glucose uptake in older people. Journal of the American Geriatrics Society 199947 1312-1318.

17 Sandhu MS, Heald AH, Gibson JM, Cruickshank JK, Dunger DB \& Wareham NJ. Circulating concentrations of insulin-like growth factor-I and development of glucose intolerance: a prospective observational study. Lancet 2002359 1740-1745.

18 Scharf JG, Schmitz F, Frystyk J, Skjaerbaek C, Moesus H, Blum WF, Ramadori G \& Hartmann H. Insulin-like growth factor-I serum concentrations and patterns of insulin-like growth factor binding proteins in patients with chronic liver disease. Journal of Hepatology 199625 689-699.

19 Plauth M, Merli M, Kondrup J, Weimann A, Ferenci P \& Muller MJ. ESPEN guidelines for nutrition in liver disease and transplantation. Clinical Nutrition 199716 43-55.

20 Harris JA \& Benedict FG. A biometric study of basal metabolism in man. Publication No 270. Carnigie Institute of Washington DC 1919.

21 Rossle M, Haag K, Ochs A, Sellinger M, Noldge G, Perarnau JM, Berger E, Blum U, Gabelmann A \& Hauenstein K. The transjugular intrahepatic portosystemic stent-shunt procedure for variceal bleeding. New England Journal of Medicine 1994330 165-171.

22 Andersen L, Dinesen B, Jorgensen PN, Poulsen F \& Roder ME. Enzyme immunoassay for intact human insulin in serum or plasma. Clinical Chemistry 199339 578-582.

23 Orskov H, Thomsen HG \& Yde H. Wick chromatography for rapid and reliable immunoassay of insulin, glucagon and growth hormone. Nature 1968219 193-195.

24 Albertsson-Wikland K, Jansson C, Rosberg S \& Novamo A. Timeresolved immunofluorometric assay of human growth hormone. Clinical Chemistry 199339 1620-1625.

25 Frystyk J, Dinesen B \& Ørskov H. Non-competitive time-resolved immunofluorometric assays for determination of human insulinlike growth factor I and II. Growth Regulation 19955 169-176.

26 Chen JW, Ledet T, Orskov H, Jessen N, Lund S, Whittaker J, De Meyts P, Larsen MB, Christiansen JS \& Frystyk J. A highly sensitive and specific assay for determination of IGF1 bioactivity in human serum. American Journal of Physiology. Endocrinology and Metabolism 2003284 E1149-E1155.

27 Krassas GE, Pontikides N, Kaltsas T, Dumas A, Frystyk J, Chen JW \& Flyvbjerg A. Free and total insulin-like growth factor (IGF)-I, -II, and IGF binding protein-1, -2 , and -3 serum levels in patients with active thyroid eye disease. Journal of Clinical Endocrinology and Metabolism $2003 \mathbf{8 8} 132-135$.

28 Tygstrup N. Determination of the hepatic elimination capacity (Lm) of galactose by single injection. Scandinavian Journal of Clinical and Laboratory Investigation 196618 118-125.

29 Matthews DR, Hosker JP, Rudenski AS, Naylor BA, Treacher DF \& Turner RC. Homeostasis model assessment: insulin resistance and beta-cell function from fasting plasma glucose and insulin concentrations in man. Diabetologia 198528 412-419.

30 Kushner RF \& Schoeller DA. Estimation of total body water by bioelectrical impedance analysis. American Journal of Clinical Nutrition 198644 417-424.

31 Lautz HU, Selberg O, Korber J, Burger M \& Muller MJ. Proteincalorie malnutrition in liver cirrhosis. Clinical Investigator 199270 478-486.

32 Pirlich M, Schutz T, Spachos T, Ertl S, Weiss ML, Lochs H \& Plauth M. Bioelectrical impedance analysis is a useful bedside technique to assess malnutrition in cirrhotic patients with and without ascites. Hepatology 200032 1208-1215.

33 Kaser S, Foger B, Waldenberger P, Nachbaur K, Propst A, Jaschke W, Vogel W \& Patsch JR. Transjugular intrahepatic portosystemic shunt (TIPS) augments hyperinsulinemia in patients with cirrhosis. Journal of Hepatology 200033 902-906.
34 Selberg O, Bottcher J, Pirlich M, Henkel E, Manns MP \& Muller MJ. Clinical significance and correlates of whole body potassium status in patients with liver cirrhosis. Hepatology Research 199916 $36-48$.

35 Scharf JG \& Braulke T. The role of the IGF axis in hepatocarcinogenesis. Hormone and Metabolic Research 200335 685-693.

36 Yakar S, Liu JL, Stannard B, Butler A, Accili D, Sauer B \& LeRoith D. Normal growth and development in the absence of hepatic insulin-like growth factor I. PNAS 199996 7324-7329.

37 Assy N, Pruzansky Y, Gaitini D, Shen Orr Z, Hochberg Z \& Baruch Y. Growth hormone-stimulated IGF-1 generation in cirrhosis reflects hepatocellular dysfunction. Journal of Hepatology 200849 34-42.

38 Ketelslegers JM, Maiter D, Maes M, Underwood LE \& Thissen JP. Nutritional regulation of insulin-like growth factor-I. Metabolism 199544 50-57.

39 Lafortune M, Martinet JP, Denys A, Patriquin H, Dauzat M, Dufresne MP, Colombato L \& Pomier-Layrargues G. Short- and long-term hemodynamic effects of transjugular intrahepatic portosystemic shunts: a Doppler/manometric correlative study. AJR. American Journal of Roentgenology 1995164 997-1002.

40 Sanyal AJ, Freedman AM, Luketic VA, Purdum PP III, Shiffman ML, DeMeo J, Cole PE \& Tisnado J. The natural history of portal hypertension after transjugular intrahepatic portosystemic shunts. Gastroenterology 1997112 889-898.

41 Surratt RS, Middleton WD, Darcy MD, Melson GL \& Brink JA. Morphologic and hemodynamic findings at sonography before and after creation of a transjugular intrahepatic portosystemic shunt. AJR. American Journal of Roentgenology 1993160 $627-630$.

42 Edgerton DS, Lautz M, Scott M, Everett CA, Stettler KM, Neal DW, Chu CA \& Cherrington AD. Insulin's direct effects on the liver dominate the control of hepatic glucose production. Journal of Clinical Investigation 2006116 521-527.

43 Stefankova J, Safka V, Fejfar T, Hulek P, Dresslerova I \& Krajina A. Effect of transjugular portosystemic shunt on insulin resistance. Vnitrní lékarství $2002 \mathbf{4 8} 1017-1024$.

44 Jessen N, Djurhuus CB, Jorgensen JO, Jensen LS, Moller N, Lund S \& Schmitz O. Evidence against a role for insulin-signaling proteins PI 3-kinase and Akt in insulin resistance in human skeletal muscle induced by short-term GH infusion. AJR. American Journal of Roentgenology 2005288 E194-E199.

45 Raddatz D, Rossbach C, Buchwald A, Scholz KH, Ramadori G \& Nolte W. Fasting hyperglucagonemia in patients with transjugular intrahepatic portosystemic shunts (TIPS). Experimental and Clinical Endocrinology and Diabetes 2005113 268-274.

46 Kondrup J \& Muller MJ. Energy and protein requirements of patients with chronic liver disease. Journal of Hepatology 199727 239-247.

47 Merli M, Riggio O, Romiti A, Ariosto F, Mango L, Pinto G, Savioli M \& Capocaccia L. Basal energy production rate and substrate use in stable cirrhotic patients. Hepatology 199012 106-112.

48 Romiti A, Merli M, Martorano M, Parrilli G, Martino F, Riggio O, Truscelli A, Capocaccia L \& Budillon G. Malabsorption and nutritional abnormalities in patients with liver cirrhosis. Italian Journal of Gastroenterology 199022 118-123.

49 Schneeweiss B, Graninger W, Ferenci P, Eichinger S, Grimm G, Schneider B, Laggner AN, Lenz K \& Kleinberger G. Energy metabolism in patients with acute and chronic liver disease. Hepatology 199011 387-393.

50 Muller MJ. Bottcher J, Selberg O, Weselmann S, Boker KH, Schwarze M, von zur Muhlen A \& Manns MP. Hypermetabolism in clinically stable patients with liver cirrhosis. American Journal of Clinical Nutrition 199969 1194-1201.

Received 4 March 2009

Accepted 9 March 2009 